University of Nebraska - Lincoln

DigitalCommons@University of Nebraska - Lincoln

Ralph Skomski Publications

Research Papers in Physics and Astronomy

March 1994

NON-EQUILIBRIUM GAS-PHASE NITROGENATION

S. Brennan

Trinity College, Dublin, Ireland

Ralph Skomski

University of Nebraska-Lincoln, rskomski2@unl.edu

J.M.D. Coey

Trinity College, Dublin, Ireland

Follow this and additional works at: https://digitalcommons.unl.edu/physicsskomski

Part of the Physics Commons

Brennan, S.; Skomski, Ralph; and Coey, J.M.D., "NON-EQUILIBRIUM GAS-PHASE NITROGENATION" (1994). Ralph Skomski Publications. 6.

https://digitalcommons.unl.edu/physicsskomski/6

This Article is brought to you for free and open access by the Research Papers in Physics and Astronomy at DigitalCommons@University of Nebraska - Lincoln. It has been accepted for inclusion in Ralph Skomski Publications by an authorized administrator of DigitalCommons@University of Nebraska - Lincoln. 


\title{
NON-EQUILIBRIUM GAS-PHASE NITROGENATION
}

\author{
S. Brennan, R. Skomski, and J. M. D. Coey \\ Department of Pure and Applied Physics, Trinity College, Dublin 2, Ireland
}

\begin{abstract}
Non-equilibrium nitrogenation of transition-metal rich rare-earth intermetallics can be used to increase the nitrogen content beyond its equilibrium concentration. For example, nitrogenation of Sm2Fe17 using ammonia yields volume expansions up to 8.3 vol $\%$, which correspond to a composition $\mathrm{Sm}_{2} \mathrm{Fe}_{17} \mathrm{~N}_{x}$ with $x \approx 4$. This effect is related to catalytic action at the metal surface where ammonia is decomposed into nitrogen and hydrogen, with nitrogen absorption on a site where it is weakly bound, as an intermediate step. For overloaded Sm2Fe17N $x$ with $x>3$ the net reaction energy $U_{0}=5 \pm 10 \mathrm{~kJ} / \mathrm{mole}$ indicates a nearly temperature-independent occupation of the non-9e sites.
\end{abstract}

\section{INTRODUCTION}

There is much evidence that quasi-equilibrium nitrogenation of $\mathrm{Sm}_{2} \mathrm{Fe}_{17}$, conducted at $400-500^{\circ} \mathrm{C}$ in about one bar $\mathrm{N}_{2}$, yields a nitride $\mathrm{Sm}_{2} \mathrm{Fe}_{17} \mathrm{~N}_{3}-\delta$ with useful hardmagnetic properties [1-4]. Neutron diffraction measurements indicate a practically exclusive occupation by nitrogen of the octahedral $9 \mathrm{e}$ interstices in the rhombohedral $\mathrm{Th}_{2} \mathrm{Zn}_{17}$ structure [5], when these nitrogenation conditions are used.

On the other hand, some authors report nitrogen contents $x \approx 6$ after treatment in ammonia or hydrogen which are incompatible with an exclusive occupation of the $\mathrm{Sm}_{2} \mathrm{Fe}_{17} 9 \mathrm{e}$ octahedra. No structural data are yet available, but the observed volume expansion (about $7.5 \%$ in [6]) is little greater than that for $\mathrm{Sm}_{2} \mathrm{Fe}_{17} \mathrm{~N}_{3}$.

Here we discuss the possibility of a nitrogen content $x$ $>3$ within the framework of non-equilibrium thermodynamics and statistics. We present data indicating the catalytic action of $\mathrm{Sm}_{2} \mathrm{Fe}_{17}$ for ammonia decomposition, which is attributed to occupancy of sites other than $9 \mathrm{e}$ octahedra.

\section{STATISTICAL BACKGROUND}

Neglecting interatomic interaction effects, the equilibrium nitrogen solubility on the $9 \mathrm{e}$ sites is given by $[3,4]$

$$
x=3\left(1+\sqrt{\frac{p_{o}}{p}} e^{U_{o} / k T}\right)^{-1}
$$

with $\mathrm{p}_{\mathrm{o}}$ constant $\approx 100 \mathrm{kbar}$ and $\mathrm{U}_{\mathrm{o}}$ the net reaction energy (nitrogen absorption energy). The sign and magnitude of $U_{o}$ determine whether the nitrogen uptake is high or low. The experimental value $U_{0}=-57 \mathrm{~kJ} /$ mole for $\mathrm{Sm}_{2} \mathrm{Fe}_{17}[3,4]$ indicates a high solubility, whereas the value for $\alpha-\mathrm{Fe}, \mathrm{U}_{0}=$ $30 \mathrm{~kJ} / \mathrm{mole}$ [7], means a very low solubility.

From the point of view of equilibrium thermodynamics there is no advantage in using ammonia instead of molecular nitrogen. The formation of ammonia from nitrogen and hydrogen is exothermic $\left(U_{0} \approx-45 \mathrm{~kJ} / \mathrm{mole}[8,9]\right)$, but the large entropy contributions from the hydrogen and nitrogen gases outweigh the energetic effect. Correspondingly, the concentration of ammonia under typical nitrogenation conditions ( 1 bar pressure and $500^{\circ} \mathrm{C}$ ), if it were in equilibrium with hydrogen and nitrogen, would be negligibly small (less than $1 \%$ ).

The situation changes, however, if the ammonia partial pressure is kept artificially high. Ammonia then decomposes catalytically at the metal surface, which involves the formation of an intermediate nitride. Note that nitrogen desorption and adsorption are known to be the rate-limiting steps in ammonia catalysis $[8,10]$. This intermediate nitrogenation is a possible way to produce overloaded nitrides having $x>3$.

\section{RESULTS}

To investigate the catalytic activity and the nitrogenation behaviour of the intermtallics, ingot samples were milled for 15 minutes under cyclohexane. After drying and sieving, a narrow particle size distribution, typically $10-15 \mu \mathrm{m}$, was obtained. To monitor the gas pressure as a function of time and temperature, the reaction was conducted in the quartz sample tube (volume $=6.3 \mathrm{~cm}^{3}$ ), of a thermopiezic analyser (TPA), connected to mass spectrometer. Fig 1 shows the ammonia concentration deduced from the total pressure. X-ray powder diffraction with $\mathrm{Cu} \mathrm{K}_{\alpha}$ radiation was used for phase analysis and determination of the lattice parameters.

Fig. 2 shows the effect of $\mathrm{Sm}_{2} \mathrm{Fe}_{17}$ on the catalytic decomposition of ammonia. The catalyzed decomposition starts at about $300^{\circ} \mathrm{C}$, compared to about $550^{\circ} \mathrm{C}$ in an empty quartz tube. Other experimentally determined onset temperatures are $450^{\circ} \mathrm{C}$ for $\mathrm{Y}_{2} \mathrm{Co}_{17}, 400{ }^{\circ} \mathrm{C}$ for $\mathrm{Y}_{6} \mathrm{Fe}_{11} \mathrm{Ga}_{3}$, $350^{\circ} \mathrm{C}$ for $\mathrm{Fe}, \mathrm{Co}$, and $\mathrm{SmCo}_{5}$, and $300^{\circ} \mathrm{C}$ for $\mathrm{Y}_{2} \mathrm{Fe}_{17}$.

To investigate the initial stage of the reaction, the isothermal decomposition curves were fitted to the solution of the Temkin equation [9].

$$
\frac{\mathrm{dN}_{\mathrm{A}}}{\mathrm{dt}}=\mathrm{k}_{1} \mathrm{pN}_{\mathrm{N}}\left(\frac{\mathrm{pH}^{3}}{\mathrm{pA}^{2}}\right)^{\alpha}-\mathrm{k}_{2}\left(\frac{\mathrm{pA}_{\mathrm{A}}^{2}}{\mathrm{pH}^{3}}\right)^{1-\alpha}
$$




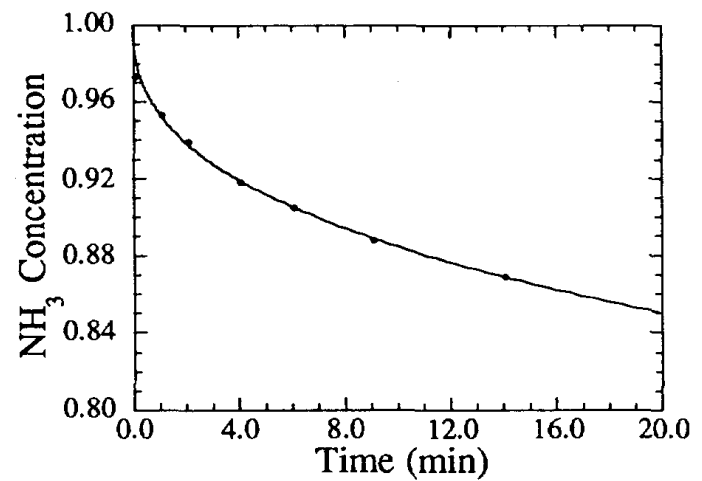

Fig. 1 Reduced ammonia concentration as a function of time for a short isothermal experiment at $425^{\circ} \mathrm{C}$ with a $\mathrm{Sm}_{2} \mathrm{Fe}_{17}$ catalyst.

Here $\mathrm{N}_{\mathrm{A}}$ is the total number of hydrogen atoms in the system, and $\mathrm{p}_{\mathrm{A}}, \mathrm{pN}_{\mathrm{N}}$, and $\mathrm{p}_{\mathrm{H}}$, are the partial pressures of the three gasses involved. Results are $\alpha=0.75 \pm 0.10$ for $\mathrm{Y}_{2} \mathrm{Co}_{17}, \alpha=0.75 \pm 0.20$ for $\mathrm{Fe}$, and $\alpha=0.77 \pm 0.15$ for $\mathrm{Sm}_{2} \mathrm{Fe}_{17}$. Though preliminary, these results, as well as the corresponding catalytic activities $\mathbf{k}_{2}$ [11], indicate a similiar catalytic behaviour for all the compounds investigated [12].

To obtain materials with nitrogen contents $x>3$, $\mathrm{Sm}_{2} \mathrm{Fe}_{17}$ powder was heated in pure ammonia (Table 1). The volume expansion of $8.3 \%$ (cf. Fig. 3 ) clearly indicates that nitrogen occupancy is not restricted to the 9e sites. Assuming a unit cell expansion of about $2.1 \%$ per per nitrogen atom (cf. the corresponding consideration for hydrogen in metals [13]), we obtain a nominal composition $\mathrm{Sm}_{2} \mathrm{Fe}_{17} \mathrm{~N}_{4}$. Higher nitrogen uptake (up to $x=6.25$ ) leads to the formation of $\mathrm{Fe}_{4} \mathrm{~N}$ and SmN. Other intermetallics, such as SmCo5, become amorphous upon ammonia treatment.

Neglecting interatomic interaction effects and nitrogen outgassing, the nitrogen concentration on the non-9e sites is given by [11]

$$
c=\left(1+\sqrt{\frac{p_{H}^{3}}{p_{A}^{2} p_{c}}} e^{\left(U_{o}-U_{A}\right) / k T}\right)^{-1}
$$

Compound $\mathrm{Sm}_{2} \mathrm{Fe}_{17} \mathrm{Sm}_{2} \mathrm{Fe}_{17} \mathrm{~N}_{3-\delta} \quad \mathrm{Sm}_{2} \mathrm{Fe}_{17} \mathrm{~N}_{3+\delta}$

\begin{tabular}{lccc}
\hline $\mathrm{a}(\AA)$ & 8.535 & 8.719 & 8.745 \\
$\mathrm{c}(\AA)$ & 12.434 & 12.635 & 12.832 \\
$\Delta \mathrm{a} / \mathrm{a} \%$ & 0.0 & 2.2 & 2.5 \\
$\Delta \mathrm{c} / \mathrm{c} \%$ & 0.0 & 1.6 & 3.2 \\
$\mathrm{v}\left(\AA^{3}\right)$ & 784.4 & 831.8 & 849.9 \\
$\Delta \mathrm{v} / \mathrm{v} \%$ & 0.0 & 6.0 & 8.3
\end{tabular}

Table 1. Crystallographic data for nitrides of $\mathrm{Sm}_{2} \mathrm{Fe}_{17}$ produced by gas phase interstitial modification with $\mathrm{N}_{2}$ and $\mathrm{NH}_{3}$. where $p_{c} \approx 70 \mathrm{kbar}$ and $U_{o}$ is the net reaction energy for the non-9e site. Note that this equation, though formally related to Eq. (1) by the equilibrium reaction constant $k=\left(\mathrm{p}_{\mathrm{N}} \mathrm{p}^{1.5}\right) / \mathrm{p}_{\mathrm{A}}$ (cf. e.g. [14]), does not describe an equilibrium process - the equilibrium solubility is given by Eq. (1). The use of ammonia is equivalent to a huge effective nitrogen pressure, $\mathrm{p}_{\mathrm{eff}} \approx 3 \mathrm{Mbar}$ in $\mathrm{Eq}$. (1). $\mathrm{p}_{\mathrm{H}}$ and $\mathrm{p}_{\mathrm{A}}$ are controlled by the reaction conditions so $\mathrm{Eq}$. (3) can be used to estimate $U_{0}$. Based on the data given in Table 2, the value $U_{0}=5 \pm 10$ $\mathrm{kJ} / \mathrm{mole}$, is obtained from Eq. (3) taking $\mathrm{c}=[(\Delta \mathrm{v} / \mathrm{v})-6.3] / 2.1$, which indicates a weakly endothermic reaction. Table 2 compares the observed volume expansions $(\Delta V / V)_{\text {ex }}$ with values calculated $(\Delta \mathrm{V} / \mathrm{V})_{\mathrm{th}}$, using $\mathrm{U}_{\mathrm{o}}=5 \mathrm{~kJ} / \mathrm{mole}$ - the agreement is reasonably good.

\section{DISCUSSION}

The data shows that the catalytic decomposition of ammonia by transition-metal rich rare-earth intermetallics, in particular $\mathrm{R}_{2} \mathrm{Fe}_{17}$, strongly influences the interstitial modification

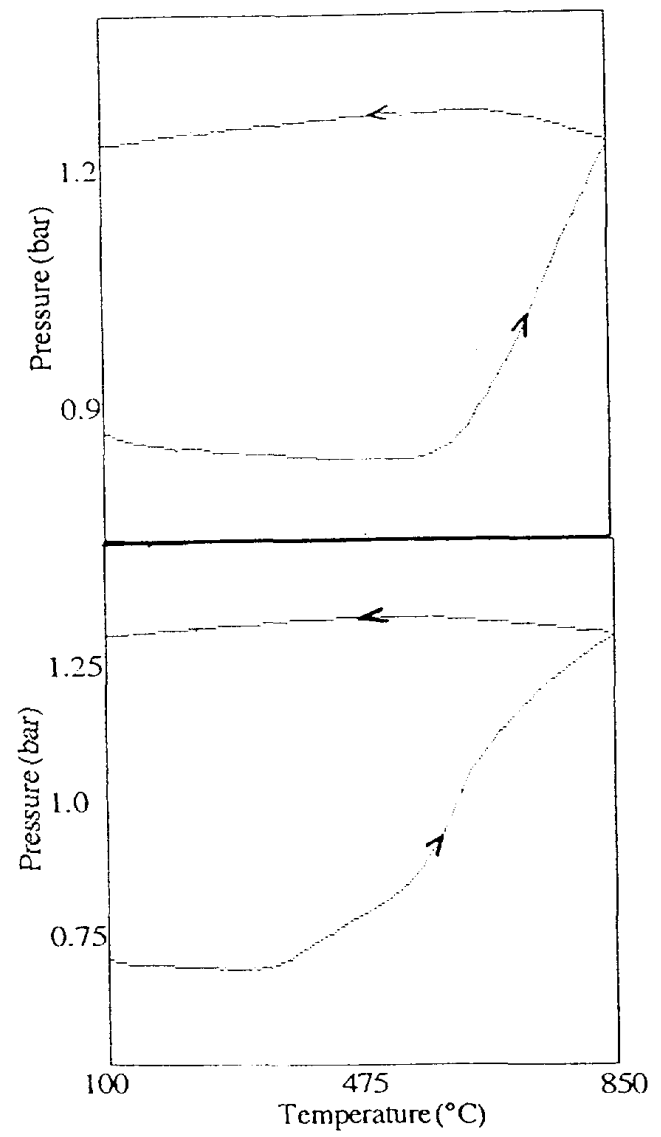

Fig. 2: TPA data, showing the ammonia decomposition in (a) an empty quartz tube, and (b) in a quartz tube containing $\mathrm{Sm}_{2} \mathrm{Fe}_{17}$ powder. The decomposition of ammonia is seen as pressure increase on the heating curve (heating rate $10^{\circ} \mathrm{C} / \mathrm{min}$ ). 
reaction. Ammonia decomposition enhances nitrogen uptake, leading to overloaded nitrides.

The additional nitrogen atoms are likely to be accomodated on the hexagon of $18 \mathrm{~g}$ tetrahedral interstitial sites or on the $3 \mathrm{~b}$ site at the centre of the hexagon, midway between two rare-earths. The nominal composition with $x=4$ corresponds to occupation of three $9 \mathrm{e}$ sites and one of the $18 \mathrm{~g}$ sites per formula unit. The possibility of nitrogen atoms on the $3 \mathrm{~b}$ site may reduce the dumbell distance which is consistant with the observed small decrease in $T_{c}\left(\Delta T_{c}=\right.$ $10 \mathrm{~K}$ ), for a sample with $7.7 \%$ unit cell volume expansion.

The occupation of two or more sites per $18 \mathrm{~g}$ hexagon $[6,14]$ is unlikely as the observed volume expansion does not support nitrogen occupancies larger than four, futhermore, even hydrogen atoms, which are much smaller than nitrogen, occupy no more than two $18 \mathrm{~g}$ sites per hexagon [15].

The net reaction energy $U_{o}=5 \pm 10 \mathrm{~kJ} / \mathrm{mole}$ indicates that the occupation of non-9e site is energetically much less favourable than occupancy of the $9 \mathrm{e}$ sites where $U_{0}=-57 \pm$ $5 \mathrm{~kJ} / \mathrm{mole}$. Putting the value $5 \mathrm{~kJ} / \mathrm{mole}$ into Eq. (1) we find that under typical nitrogenation conditions $\left(1 \mathrm{bar} \mathrm{N}_{2}, 500^{\circ} \mathrm{C}\right.$ ) there are only 0.005 nitrogen atoms per formula unit on the non-9e sites.

As far as the magnetic properties of the material are concerned, there is not much hope that the performance of the

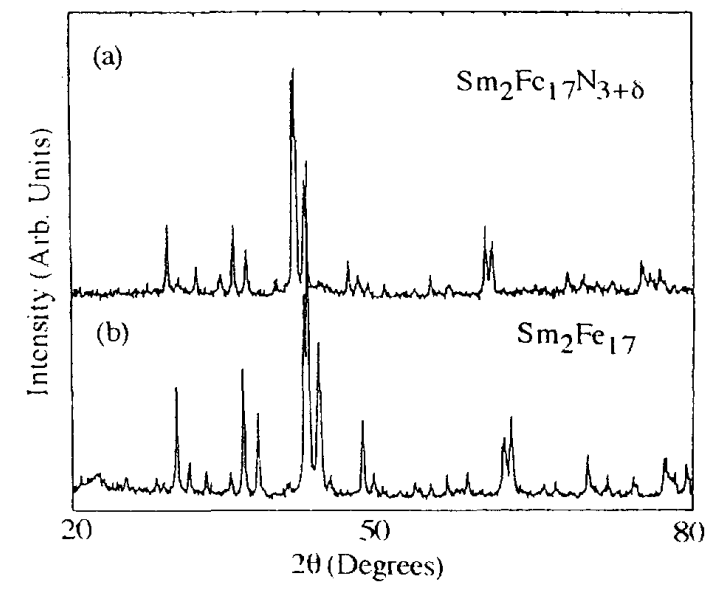

Fig 3. X-ray diffraction pattern of (a) $\mathrm{Sm}_{2} \mathrm{Fe}_{17} \mathrm{~N}_{3+\delta}(\delta \approx 1)$ and (b) $\mathrm{Sm}_{2} \mathrm{Fe}_{17}$.

$\mathrm{p}_{\mathrm{A}}[\mathrm{mbar}] \quad \mathrm{m}[\mathrm{mg}](\Delta \mathrm{V} / \mathrm{V})_{\mathrm{ex}}[\%](\Delta \mathrm{V} / \mathrm{V})_{\mathrm{th}}[\%]$

\begin{tabular}{rrrr}
\hline 110 & 9.8 & 6.7 & 6.6 \\
192 & 10.0 & 6.7 & 6.8 \\
375 & 8.9 & 6.8 & 7.2 \\
720 & 10.3 & 7.4 & 7.5 \\
1007 & 12.2 & 7.7 & 7.6 \\
1450 & 13.5 & 8.3 & 7.7
\end{tabular}

Table 2: Volume expansions for different $\mathrm{Sm} 2 \mathrm{Fe} 17 \mathrm{~N} 3+\delta$ samples $\left(\mathrm{T}=425^{\circ} \mathrm{C}, \mathrm{t}=50 \mathrm{~min}\right.$ ). magnet can be improved with respect to $\mathrm{Sm}_{2} \mathrm{Fe}_{17} \mathrm{~N}_{3}$. We can expect a reduction in anisotropy energy for $x>3$. The anisotropy energy gain, compared to the parent compound $\mathrm{Sm}_{2} \mathrm{Fe}_{17}$, in $\mathrm{Sm}_{2} \mathrm{Fe}_{17} \mathrm{~N}_{4}$ is only $1 / 3$ of that in $\mathrm{Sm}_{2} \mathrm{Fe}_{17} \mathrm{~N}_{3}$, if the excess nitrogen atom is centered at the $3 \mathrm{~b}$ site. Note that this result is qualitatively confirmed by measurements on samples with $\mathrm{x}<6[6,14]$.

\section{CONCLUSIONS}

Non-equilibrium nitrogenation using ammonia, which from a thermodynamic viewpoint is closer to ion implantation than to conventional gas-phase interstitial modification using molecular nitrogen, can be used to produced overloaded nitrides. Nitrogen absorption is an intermediate step during ammonia decomposition and it assures a nitrogen flux through the particle surface. Once in the lattice, nitrogen is subject to bulk diffusion and yields volume expansions up to $8.3 \%$, corresponding to a nitrogen content of about 4 nitrogen atoms per formula unit. The net reaction energy for the excess nitrogen atoms, which may be situated on distorted $3 \mathrm{~b}$ sites is $\mathrm{U}_{\mathrm{o}}=5 \pm 10 \mathrm{~kJ} / \mathrm{mole}$.

\section{ACKNOWLEDGEMENTS}

This work forms part of the 'Concerted European Action on Magnets'. It was supported by the BRITE/EURAM Programme of the European Commission.

\section{REFERENCES}

[1] J. M. D. Coey and H. Sun, J. Magn. Magn. Mater. 87 (1990) L251.

[2] J. M. D. Coey, H. Sun, Y. Otani, and D. P. F. Hurley, J. Magn. Magn. Mater. 98 (1991) 76.

[3] J. M. D. Coey, R. Skomski, and S. Wirth, IEEE Trans. Magn. 28 (1992) 2332.

[4] R. Skomski and J. M. D. Coey, J. Appl. Phys. (1993), in press.

[5] O. Isnard, S. Miraglia, J. L. Soubeyroux, D. Fruchart, and J. Pannetier, Phys. Rev. B 45 (1992) 2920.

[6] T. Iriyama, K. Kobayashi, T. Fukuda, H. Kato, and Y. Nakagawa, IEEE Trans. Magn. 28 (1992) 2326.

[7] J. D. Fast, Gases in Metals, MacMillan, London 1976.

[8] N. D. Spencer, G. A. Somorjai, Rep. Prog. Phys. 46 (1983) 1.

[9] J. R. Jennings and M. V. Twigg, in: Selected Developments in Catalysis, Ed. J. R. Jennings, Society of Chemical I ndustrý, London 1985.

[11] R. Skomski, S. Brennan, and J. M. D. Coey (1993) unpublished.

[12] G. Sandrock, S. Suda, and L. Schlapbach, in: Hydrogen in Intermetallic Compounds II, Ed. L. Schlapbach, Springer, Berlin 1992, p. 197.

[13] H. Peisl, in: Hydrogen in Metals I, Eds G. Alefeld and J. Völkl, Springer, Berlin 1978, p. 53.

[14] Yu-Nian Wei et al., J. Alloys Comp. 194 (1993) 9.

[15] O. Isnard et al., Physica B 180\&181 (1992) 629-631. 